\title{
Strategic Analysis for Hi-tech Enterprises to Introduce PE Investment in China
}

\author{
Jing Xiang, Susheng Wang, Zhaokun Kong \& Wenhu Li \\ Economic and Management Department \\ Harbin Institute of Technology Shenzhen Graduate School \\ Shenzhen 518055, China \\ E-mail: carol.hsiang@163.com
}

\begin{abstract}
$\mathrm{PE}$ investment is comparatively mature in developed countries. Along with the growing of PE investment in China in recent years, hi-tech enterprises of high growth potential are favored by PE investor. However, hi-tech enterprises in China are short of sufficient skills of strategy for bringing in foreign capital and objective qualifications in introducing PE investment. Therefore, this article analyzes how to enhance the skills of strategy for introducing investment and improving enterprises' objective conditions to stimulate successful cooperation between the PE investor and hi-tech projects.
\end{abstract}

Keywords: Hi-tech enterprises, PE, Strategy

\section{Introduction}

Private Equity Investment (PE Investment) refers to the investment that the capital is collected in form of private equity and invested into rights and equities of non-listed enterprises. It obtains return on initial capital by selling its holdings through listing, mergers and acquisitions, buy-back and so on. PE covers equity investment all stages before initial public offering (IPO). It can be divided into venture capital, development capital, mergers and acquisitions funds, mezzanine capital, and Pre-IPO capital according to different stages. PE is marked by following features: wide source of fund;non public capital collection and buy-back; rights investment or mix investment into non-listed enterprises;middle or long term duration; a variety of exit channels etc. PE investment funds in U.S., which increased 459 billion U.S. dollars in 2006, successfully brought up Apple Computer, Intel and other hi-tech enterprises, and the high returns attracted a large number of institutional investors to participate. According to Qing Branch Research Center, a total of 129 projects, amounted to 12 billion and 973 million U.S. dollars were invested in China by PE institutional investors in home and from abroad in 2006. With rapid development of China's capital market, upgrading of industry and consumption structure, and increasing heat-up of domestic PE investment, hi-tech enterprises of high growth potential are favored by PE investment institutions.

The introduction of PE will bring numerous advantages for hi-tech enterprises as following: opens an effective channel of financing; enhances management level; promotes technical innovation and upgrade of industrial structure; conduces to design of equity-based incentives, attraction of talents, improvement of operation efficiency, cultivation of core competitiveness and enhancement of overall value; increases binding of corporate managers; helps stability of stock price.

\section{Financing needs in different stages of hi-tech enterprises and $P E$ investment strategies}

The hi-tech enterprises generally follow such development stages: seed period, creation stage, growing stage, expanding period and maturity period (Pre-IPO), and vary at financing needs and financing characteristics in different stages. Also, $\mathrm{PE}$ has its own preferences and expertise in choice of development stage of the targeted enterprise.

Insert Talbe 1 Here

\section{The basic strategies of introducing $P E$ investments for hi-tech enterprises in China}

The newly founded hi-tech enterprises have to face different risks at different stages, such as small scale, large variable, high-risk, and short life, and so on. However, failed financing, to some extent, can be attributed to the lack of financing skills and the insufficiency of objective qualifications in general. This article will discuss how to enhance financing skills and improve the management of the enterprises respectively. 


\subsection{Enhance financing strategies and techniques}

\subsubsection{Be familiar with the operation processes of PE investments}

To introduce PE successfully, hi-tech enterprises should understand the operation processes of PE investment firstly. The operation processes of PE investment are as following: (1) The project investigation stage: ventures or projects are found more or less in line with PE investment conditions from a number of proposals, and then extensive, in-depth and detailed investigations are conducted to obtain full and accurate first-hand information for decision-making analysis. (2) The evaluation and decision-making stage: Based on relevant information, objective analysis and evaluation are made on human resources, technology, marketing and management of investment projects. Risks, which exist in all aspects of growth and development of targeted enterprises and product technology, must be taken into account. According to investors' own capacity and to the scale and criteria of investment, projects with lower market risk and larger growth potential are given priority. (3) Negotiation and contract Signature: PE investment institutions will contact with targeted firms after choosing project and negotiate together for investment mode and conditions, and reach relevant legal agreements.(4) Investment operational phase: PE investment institutions should provide financial supports to enterprises according to their agreements, contact with entrepreneurs regularly to track the progress of firm operation, and have the financial reports audited by accounting firms. They are also required to support enterprises by using their own management experience and information network, cooperate closely with enterprises in order to make them high-valued and mature ones, promote investment projects running successfully and get enterprises listed. (5) Incentive and restrictive measures in the process of investment: the provisions such as rights owned by PE investors to quit,to buy back enterprises, arrangement of remuneration system for managers and investors will normally be made in the investment agreement. Right to quit will protect PE investors to some extent, and right to buy back enterprises will motivate entrepreneurs to operate by efforts. Furthermore, PE investors take stern sanctions against any improper usage of capital to ensure managers to cherish it. (6) Investment quit: The ultimate aim for PE investment is high returns and successful withdrawal of capital. There are different exiting approaches according to the diversities of operating conditions and external environment, including publicly listed, transfer of shares, bankruptcy liquidation, etc. The former twos are the main exiting approaches, while bankruptcy liquidation is the only alternative for investment failure.

Insert $\mathrm{F}$

\subsubsection{Choose the right PE investor}

Before choosing a most suitable and promising PE investor, Hi-tech enterprises must start from their own conditions and strategic objectives, consider various factors while selecting several potential PE investors to contact. (1) Various PE investment policies and preferences. Each PE investor will establish their own investment policies and form their own investment preferences on the basis of their respective geographical conditions, source of funds, own experience and industrial competition. Enterprises must fully understand and master the PE investment policies and preferences, and then select the right one according to the industry characteristics and the development stage of company and other factors. (2) Knowing well about PE investment process and operation model. It needs to learn more about PE investment operation models, especially finding out the detailed process for evaluating projects before starting the financing process, and learn to analyze enterprise itself objectively from others' perspectives. (3) Adequacy of sources of PE capital. From the perspective of capital, when choosing a PE investor, following must be taken into account: whether its sources of funding are able to help businesses succeed and whether they are able to meet the need for enterprise' development in the future. (4) The reputation of PE investor. Hi-tech enterprises should review PE investor's performance, reputation, ethics and other actual situations through a variety of channels (such as lawyers, accountants and enterprises invested by them previously). (5) Importance on the assistance of professional institutions. The introduction of PE investment is a high professional process, and it is difficult to succeed by relying on one's own financial staffs only. Experienced financial adviser can give companies a full range, professional assistance. It increases success chances of PE investment by making full use of experienced intermediaries and communicating regularly with investment advisers. (6) Not too many targets. In order to ensure successful financing, entrepreneurs should not contact too many PE investors at one time. On the one hand, PE investors prefer to find those business opportunities abandoned by the side of road without any attention. On the other hand, it is not efficient and effective if entrepreneurs look for PE investors one by one. Therefore, the most reliable way is to select 8-10 PE investors likely being interested in the project as targets, knowing about their situations well, and then contact with them.

\subsubsection{Master the basic financing processes}

Hi-tech enterprises have same financing process with common firms. Generally, financing process includes the following aspects: (1) Plan the overall capital operating program by capital demander. It includes private equity financing, restructuring listing, and overall planning during the listing. (2) Write "business plan" (including "Investment Proposal"). (3) Contact and screen out the proper investors: Investigate the background and development status of investor prudently, and make initial contact. (4) Financing recommendation and business negotiation. (5) Provide "enterprise value assessment report" (mainly enterprise's growth assessment) for the enterprise by considering various 
assessment models totally, combined with the assessment style of potential investors. (6) Bring in the audit, evaluation and legal and other intermediary institutions to complete the making and subscription of equity financing agreements. (7) Deal with the delivery, verification, industrial and commercial registration change and other things related to change of ownership (8) Harmonize the relationship between parties, and control the financing progress.

\subsubsection{Make a good business plan}

Business plan, as the important foundation for PE investor to assess and choose enterprise, is a stepping stone to get PE investment. It allows the potential investor a quick summary to assess the project's value, acts as the basic document for the investigation and negotiation. It can also prove the enterprises ability and demonstrate the pro-and-cons of the project to PE investor. The truth and content integrity of business plan will provide PE investor effective access to information, and make a favorable assessment preparations for the project. From standpoint of investors, a good business plan should include a detailed analysis of market size and market share, a clear explanation of business model, a set of talents on technique, management, marketing and other aspects to build up a team, a scientific cash flow forecast and a practical and realistic financial planning. A comprehensive business plan is required to reflect the business idea, the sophisticated plan and management level, as well as the strong aspirations to success and the responsible attitudes to PE investment.

At the time of writing Business plan, some adjustments should be made to emphasize different parts and highlight different contents related to specific growth stage and industry characteristics. At the same time, the writing of business plan should be in honest attitude and well-founded. Only the adequate data, objective and fair expression of the problem can obtain the trust of PE investor.

\subsubsection{Learn document submission, negotiation strategy and skills}

(1) Three main documents should be ready by hi-tech entrepreneurs before starting to discuss financing issues with PE investors: 1) investment proposal: make a summary description of management, profit situation, strategic position of venture enterprises, etc.; 2) business plan: make a detailed description of development strategies, marketing promotion plans, financial condition and competitive position of venture enterprises, etc.; 3) marketing materials: These are documents directly or indirectly related to the sales of products or services of venture enterprises. (2) It's better to get recommendation from members in the extension of PE network while submitting "business plan". Most PE investors will receive hundreds of copies of "business plan" each month and don't have enough time and energy to carry out detailed examination on each plan. However, the "business plan" recommended by enterprises will cause PE investors' attention, so that will be finalist in much greater probability in previous rounds of screening. (3) Investors would normally carry out "due diligence" in making investment decision, so the core team of entrepreneurs cannot be blindly optimistic on their products, and should adopt a positive attitude while using data and facts to explain. (4) Learn to compromise. Enterprises should put their own positions in the process of negotiation, give full consideration to the interests of institutional investors, and make adequate assurances in the implementation. Introducing PE investment is not only receiving funds, but also value-added services after investment. Entrepreneurs should know very well how much compromise can be made at this stage, because it's not so realistic for the investment side to make a compromise.(5) Be both forward and backward while making agreement. Investors and financing parts are the unity of contradictory and interests. Investors often want some provisions to make their own investment out of risk. For example, "If the performance of enterprises in a particular period does not reach a certain level, investors may be able to reduce investment or enterprises are required to refund the investor." Such provision may not be accepted by enterprises. Enterprises must have the courage to say no to those PE investments not good to enhance shareholder's value.

\subsection{Improve enterprise management for assessment by PE investors}

\subsubsection{Enhance the market competitiveness}

(1) Proper market positioning. Market position reflects the operation strategy, so it is necessary to clearly define the role in industrial chain, and identify product position in market. According to differences of funds, equipment, human resource, technology and commodities, enterprises should make vertical or horizontal labor divisions, produce finely,meticulously,professionally and in-depth, adjust product structure on time, and improve the core competitiveness continuously. (2) Business model or profit model definition. Business model mainly refers to how to produce, provide services, carry out marketing plan and such other issues. Profit model concerns about how to create a profit, and how to change the products and services into profits. Many entrepreneurs only focus on their business models, but lack of thinking and specific description of the profit model, thus difficult to bring an effective attractiveness to PE investors. It is the main reason that $90 \%$ of the business plans are scanned once and then shelved by the investment managers. (3) A clear and powerful marketing strategy construction. The market is unpredictable, which hides many uncertainties. The capacity to predict market demand, the degree of being familiar with the targeted market, the ability to respond to the market changes affect the marketing capacity and have a significant impact on the success of enterprise products in the market. It's needed to have strategic vision and the insight of market opportunities to analyze the industry and market 
competition in which enterprises are intending to enter and participate in competition. (4) Long-term development strategy. The overall quality of Chinese enterprises varies: many hi-tech enterprises lack rationality,ability to judge and control, management and operation being out of control, overlook the development strategy, shorter corporate life, therefore it is difficult to obtain recognition of PE investors. Even though some hi-tech enterprises have started the research, formulation and implementation of development strategy, there are still some serious shortcomings: 1) unclear understanding and blindly climbing in the formulation of strategic objectives; 2) scale expansion in lieu of capacity expansion, and one-sided pursuit of diversification in the choice of development strategies; 3) laggard organizational structure of enterprises and serious shortage of high-quality talents in the strategy implementation.

\subsubsection{Improve the corporate governance structure}

(1) Set up a strict management system. Hi-tech enterprises in China are normally managed by the owner of enterprise technology, lacking a scientific management system. Generally management chaos and such other problems are not much obvious in enterprise's start-up stage, but becoming increasingly prominent with the expansion of production scale. Therefore, it's required to establish a strict management system, standardize organizational structure, department responsibilities,incentive and punishment, personal responsibility, so that enterprises can leap from "the rule of man" to "the rule of law" to avoid the management chaos brought about by the rapid development of enterprises. (2) Establish an effective decision-making mechanism. Property rights are highly concentrated and the boards constitutes are unreasonable in the newly established high-tech enterprises, in which operating lacks criterion and effective restraint mechanism. There is a strong speculative adventurism in investment decision-making. And hi-tech enterprises are characterized by large investment and fast product updates, which brings decision-makers an enormous challenge. Once error decision was made, it might cause irreparable loss. Therefore, hi-tech enterprises should establish effective decision-making mechanism to reduce the expected risk by PE investors. (3)Found an effective incentive mechanism. Incentive mechanism is dynamic to stimulate efficient operations of enterprise, which can promote the creation and development of enterprises. The implementation of the ESOP, which relates to the fact that the core managers can bear risk with PE investors, is an important criterion for PE investors to choose targeted enterprises. Therefore, enterprises should format such incentive system in characteristic of offering high-middle technical and managerial talents rights in the enjoyment of stock options or allowing technology, management equities. (4) United and complementary core team. There are three most important factors to determine the success of projects: the cooperative spirit and attitude of the operators, managers, shareholders; personnel being reasonably complemented in knowledge structure, experience, character and ability, etc.; and the level of team members' unity, cooperation and joint efforts as well. These three factors are also the focuses of PE investors. (5) Stable business team. Entrepreneurial team members can often unify their thinking and understanding in the early of new enterprises, however, they prone to diverge as the business develops to a certain size, which causes impact on the further development of enterprises, and may even lead to the division of company's core management, and harm the profit of investors. It is an important link in the process of attracting investment to prove to investors how to maintain the stability of entrepreneurial team and prevent the subversive effects of enterprises from differentiation of entrepreneurial team.

\subsubsection{Standardize financial management}

(1) Clarity of enterprise property rights. Although guarantees and collaterals are not required by PE investment, hi-tech enterprises are often limit-sized, lacking of accumulation and funds, with small proportion of fixed assets. If the land, factory buildings, equipment and other property were incomplete, or property rights of enterprises owned by a principal member of the family were not clear, it is even more difficult for external investors to be secure. (2) Improvement of employment mechanism and introduction of high-quality financial personnel. The financial terms have been seen as top secret by the entrepreneur, so it is a practice of nepotism while choosing the financial manager at the initial stage and the majority of positions is dominated by family members. Lacking of high-quality financial personnel led to a weak financial management, so as to further aggravate the difficulties of attracting investment. (3) Sound financial management system. A sound financial accounting system should be obtained to strengthen internal control and able to provide accurate, timely and complete financial accounting statements to enable investors to know and grasp the real condition of production and management and use of funds. (4) Reduction of violations to standardize enterprises management. There are irregularities in the development process of private hi-tech enterprises, which may result in issues such as performance not consecutive, not enough to raise funds and difficult to make adjustments. This is an important reason causing difficulties in attracting investment. (5)Transparency increases for financial information. Following is the keys to success of funding: smooth and fast communication, very high degree of transparency of information disclosure between companies and investors in the absorption of PE investment, or public equity financing. In order to avoid taxes or for other considerations, some enterprises provide investors with not comprehensive and accurate financial information and have a serious shortage of historical information available thus it is often very difficult to meet the demands of investors and obtain the trust from investors . In order to safeguard their own interests, funds providers set up standards and restrictions for enterprises to bound the risk of moral hazard, therefore also exacerbate the difficulty of attracting investment. 


\subsubsection{Reasonable plans for the demand and use of funds}

(1) The size of funds necessary to enterprises should match to the investors' strategy. The choice of investment scale is a trade-off between scale of benefits and risk separation. If scale of individual investment is too small, the total cost of investors will go up, because no matter what the scale of investment project is, investors will be needed to spend same time to monitor, and then prone to the phenomenon of diseconomies of scale. Conversely, when capital demand is very large, companies have to bear a corresponding higher risk. Hence investor will invest in suitable projects and choose appropriate scale of investment in accordance with its own investment strategy and fund size. Generally, PE funds have the upper and lower limits on the scale of investment. Lower limit is due to PE investors' taking the form of portfolio investment, and by reason of time and energy constraints, they cannot spread their investments to many small-scale projects. However, investment ceiling comes from the total amount of PE and policies to diversify the investment. A reasonable scale of capital demand should be within the scope of PE investors and the initial investment groups' power. It's the only way they can get higher returns. (2) The scale of funds required should match the development plan. A reasonable scheme for fund-using is needed to put forward to inform investors the purpose of corporate finance and how to use the money after the success of financing. Investors hope that companies will get the funds for the expansion of enterprise scale, rather than for the purchase of fixed assets having nothing to do with production and operation, or for the investment in the industry having nothing to do with itself. On the other hand, PE investors are concerned about whether the financing company can achieve growth rate and how much capital is needed to invest in the company in order to achieve the planned growth rate.

\subsubsection{Meet PE investors' high return requirements}

(1) Reach PE investment requirements of high rates of return. Due to new enterprises' high-risk nature, venture investors are bound to require a higher rate of return to compensate for higher risks. For example, the expected return on investment in seed period and start-up phase of the projects is generally higher than long-term and maturity ones. The growth rate of sales being $25-100 \%$ is a normal phenomenon in start-up phase, and $25 \%$ is the minimum data. (2) Dredge withdrawal channels of funds. Cash investment is the basic premise of PE investment. At the premise of same level of benefits, the higher the liquidity of exit channels, the lower the investment risk. For emerging markets, open channels seem more important than other factors. Three quit ways expected by PE investment are as following: Being listed in the stock market, sale of companies and buying back. The capital market is undoubtedly the withdraw path with best yield. If there are obstacles on IPO, mergers, transfer in OTC market and company repurchase, they should be cleared as soon as possible.

\section{Conclusions}

Introduction of PE investment can accelerate the development of hi-tech enterprises. However, PE investors usually consider cooperation with China's hi-tech enterprises very cautiously due to their high-risk and shortness of objective qualifications. Therefore, hi-tech enterprises have to select a reasonable financing strategy in accordance with objective qualifications, enhance negotiating skills, improve management as soon as possible, and make necessary preparations for assessment by PE investors, so as to facilitate the financing progress smoothly.

\section{References}

Cao Honghui, Hiu Huazhao. (2008). Development and economics rationality of PE, China Securities Journal, Mar 27. Roberto Ippolito. (2007). Private Equity in China and India. The Journal of Private Equity. Fall. Vol. 10, Iss. 4; pg. 36.

Tien Chengli, Ho Yvonne, Chiu Hongjen. (2008). Does the involvement of private equity investments matter to firm performance and internationalization. Journal of American Academy of Business, Cambridge. Sep. Vol. 13, Iss. 2; pg. 102.

Timothy B Folta, Jay J Janney. (2004). Strategic benefits to firms issuing private equity placements. Strategic Management Journal. Mar. Vol. 25, Iss.3; pg.223.

Xiang Jing, Wang Susheng. (2009). What caused the failure of the cooperation between high-tech enterprises and the PE investors in China? World Sci-tech R \& D. Mar. pg. 22.

Zhang Xiaojun. (2004). The research of the governance problem of PE investment [D], Mar, pg36. 


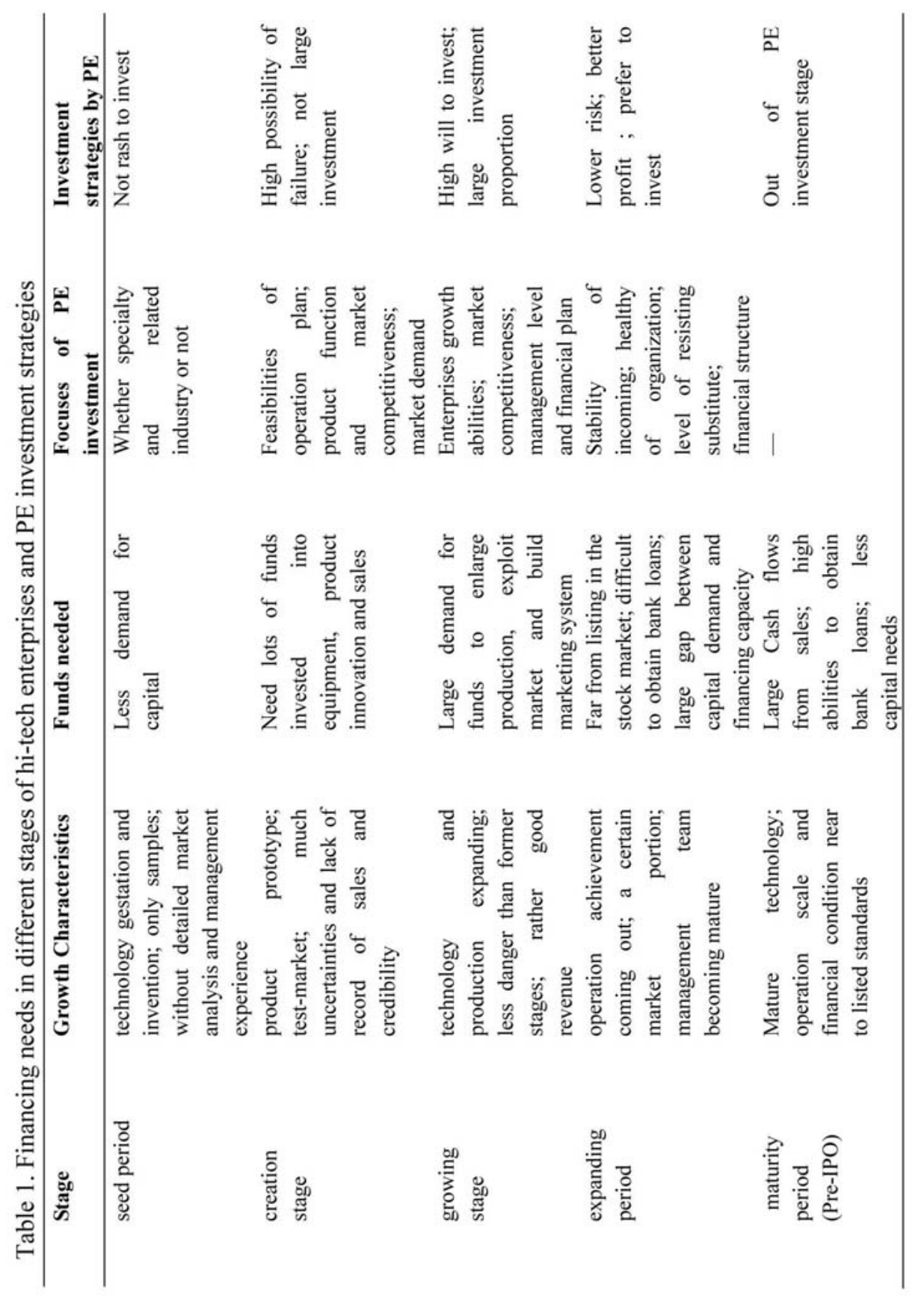




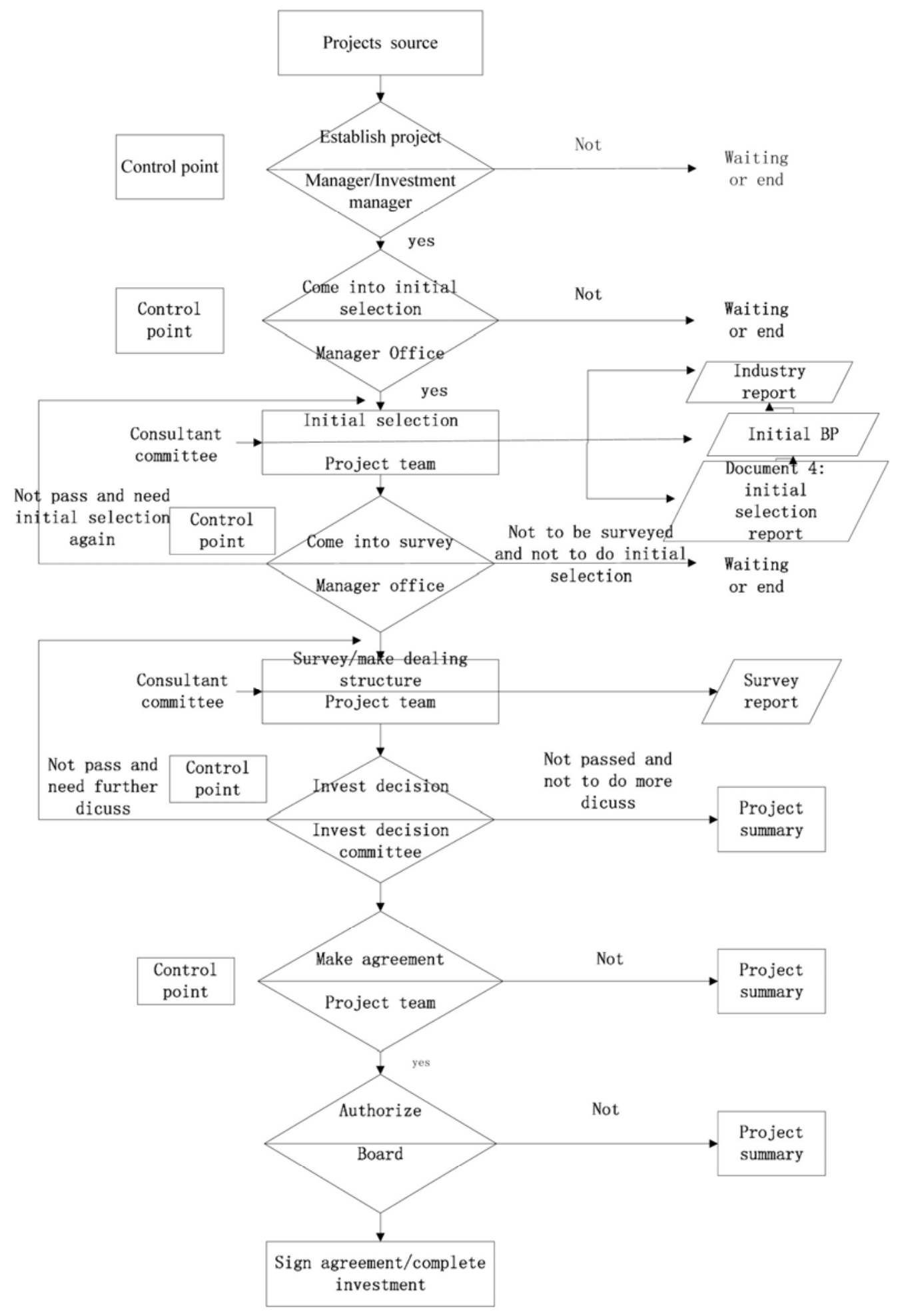

Figure 1. Project selection and decision-making process of PE investment 